\title{
KADAR HEMOGLOBIN PEKERJA PENYEMPROT GULMA AKIBAT PAPARAN PESTISIDA DI PERKEBUNAN KELAPA SAWIT
}

\section{HAEMOGLOBIN LEVEL DUE TO PESTICIDE EXPOSURE ON WORKERS SPRAYER AT PALM OIL PLANTATION}

\author{
Maksuk, ${ }^{1}$ Dian Pratiwi, ${ }^{2}$ Maliha Amin, ${ }^{1}$ Suzanna ${ }^{3}$ \\ ${ }^{1}$ Poltekkes Kemenkes Palembang, Sumatera Selatan, Indonesia \\ ${ }^{2}$ Sekolah Tinggi Ilmu Kesehatan Bina Husada, Sumatera Selatan Indonesia \\ ${ }^{3}$ Balai Teknik Kesehatan Lingkungan Palembang, Sumatera Selatan Indonesia \\ (Penulis korespondensi: maksuk@poltekkespalembang.ac.id)
}

\begin{abstract}
ABSTRAK
Latar belakang: Penggunaan pestisida yang tidak sesuai aturan dapat menimbulkan gangguan kesehatan pada manusia termasuk pekerja. Penelitian ini bertujuan untuk menganalisis kadar hemoglobin pekerja penyemprot gulma akibat paparan pestisida di perkebunan kelapa sawit.

Metode: Penelitian ini merupakan penelitian observasional analitik dengan desain penelitian ini adalah potong lintang (cross sectional) yang dilaksanakan di perkebunan kelapa sawit Kabupaten Banyuasin. Besar sampel sebanyak 80 responden, pengambilan sampel dilakukan secara acak sederhana. Analisis data dilakuka secara univariat, bivariat menggunakan uji $t$ dan analisis multivariat dengan uji regresi linier ganda.

Hasil: hasil uji t menunjukkan bahwa variabel yang secara statistik berhubungan dengan kadar haemoglobin yaitu jenis kelamin ( $\mathrm{pv}=0,005)$, tingkat pendidikan $(\mathrm{pv}=0,001)$, makan /minum saat penyemprotan $(0,032)$, penggunaan alat pelindung diri $(\mathrm{pv}=0,009)$ dan dekontaminasi setelah penyemprotan ( $\mathrm{pv}=0,001)$. Hasil uji regresi linier ganda menunjukkan bahwa variabel yang menjadi prediktor dalam menentukan kadar hemoglobin yaitu tingkat pendidikan dan dekontaminasi setelah penyemprotan

Kesimpulan: Kadar hemoglobin pekerja penyemprotan gulma ditentukan oleh beberapa variabel yaitu jenis kelamin, tingkat pendidikan, makan/minum saat penyemprotan, penggunaan alat pelindung diri dan dekomtaminasi setelah penyemprotan. Oleh karena itu penggunaan pelindung diri sangat direkomendasi bagi pekerja yang terpapar pestisida.
\end{abstract}

Katakunci: Paparan Pestisida, Kadar hemoglobin, Perkerbunan sawit

\begin{abstract}
ABSTACT
Background: The use of pesticides that do not comply with the rules due to health problems in humans, including pesticide sprayers. This study aimed to analyze the hemoglobin levels of weed spraying workers due to exposure to pesticides in oil palm plantations.

Methods: This research was an observational analytic study with a cross sectional design, this study was conducted at palm oil plantation. The samples size were 80 respondents, and samples collected with random sampling. Data analysis was used univariate, bivariate using $t$ test and multivariate analysis with multiple linear regression.

Results: the t test results showed that the variables were related to hemoglobin levels i.e. sex ( $p v=$ $0.005)$, level of education ( $p v=0.001)$, eating / drinking while spraying (0.032), use of personal protective equipment $(p v=0.009)$ and decontamination after spraying $(p v=0.001)$. The results of the multiple linear regression test showed that the variables that were predictors in determining hemoglobin levels were the level of education and decontamination after spraying

Conclusion: Hemoglobin levels of weed spraying workers are determined by several variables, namely sex, education level, eating / drinking when spraying, use of personal protective equipment and decomtamination after spraying. Therefore the workers should be using of personal protective equipment.
\end{abstract}

Keywords: Pesticide exposure, Hemoglobin level, Palm oil plantation 


\section{PENDAHULUAN}

Pestisida adalah semua zat kimia dan bahan lainnya yang digunakan digunakan untuk memberantas atau mencegah hama penyakit yang merusak tanaman dan gulma. ${ }^{1}$ Penggunaan pestisida untuk aktivitas perkebunan dan pertanian semakin meningkat termasuk perkebunan kelapa sawit yang merupakan salah satu komoditas yang sangat diminati saat ini di Indonesia termasuk Provinsi Sumatera Selatan. Luas perkebunan sawit semakin meningkat akibat alih fungsi lahan termasuk di Provinsi Sumatera Selatan, sampai dengan tahun 2013 luas areal perkebunan kelapa sawit mencapai 928.233 Ha, sedangkan di Kabupaten Banyuasin seluas 141.238 $\mathrm{Ha}^{2}$ Pengelolaan perkebunan kelapa sawit tentunya membutuhkan tenaga kerja yang cukup banyak, untuk menghemat tenaga kerja dan meningkatkan produktivitas hasil perkebunan sawit pestisida masih menjadi pilihan utama bagi masyarakat, pemerintah maupun perusahaan. Saat ini jumlah tenaga kerja yang bekerja di perkebunan kelapa sawit Provinsi Sumatera Selatan sebanyak 205.759 pekerja dan di Kabupaten Banyuasin sebanyak 18.104 pekerja. $^{2}$

Penggunaan pestisida merupakan cara yang paling praktis, ekonomis dan efisien yang digunakan di perkebunan sawit. Namun dampak negatifnya seperti meningkatnya residu pestisida di lingkungan dan gangguan kesehatan terhadap manusia menjadi masalah yang harus diperhatikan secara serius baik oleh pengguna, produsen dan juga pemerintah. Residu pestisida di lingkungan menyebabkan pencemaran lingkungan dan juga menimbulkan gangguan kesehatan bagi penggunanya dan masyarakat sekitar apabila digunakan tidak sesuai prosedur. Berdasarkan informasi yang diperoleh dari pemilik perkebunan sawit bahwa pestisida yang paling sering digunakan di perkebunan sawi adalah paraquat dan glifosat. Glifosat merupakan bahan aktif pestisida golongan organofasfat yang dapat menghambat kerja enzim kolinestrase dalam tubuh. ${ }^{3}$

Berbagai gangguan kesehatan berupa gejala atau penyakit yang dapat dialami pengguna pestisida termasuk pekerja, karena pekerja merupakan orang pertama yang langsung terkena dampak aplikasi pestisida. Salah satu gangguan pestisida berupa gejala yang paling sering dialami pekerja adalah gangguan kulit seperti kulit gatal dan kemerahan. ${ }^{4}$ Selain itu dapat menyebabkan penuruan kadar hemoglobin pekerja yang disebabkan kerusakan protein sehingga mengganggu pembentukan oksihaemoglobin sel darah merah dalam tubuh. ${ }^{5}$

Beberapa penelitian sebelumya terkait anemia pada pekerja dilaporkan bahwa pada petani Hortikultura yang terpapar pestisida terdapat $42,5 \%$ menderita anemia, ${ }^{6}$ sedangkan di perkebunan kelapa sawit ditemukan kadar Hemoglobin $8 \mathrm{~g} / \%$ - 10g/\% sebanyak $93,8 \%$ atau diklasifikasikan sebagai anemia ringan. ${ }^{7}$ Selain itu penurunan nilai rerata hemoglobin secara signifikan pada kelompok penyemprot pestisida di perkebunan mangga Malihabad. ${ }^{8}$ Paparan pestisida juga dilaporkan menyebabkan anemia pada petani Kabupaten Brebes sebanyak 15,6\%, ${ }^{9}$ sedangkan $80,8 \%$ kejadian anemia pada petani di desa Tejosari Kecamatan Ngablak. ${ }^{10}$ Selain itu paparan pstisida pada pemotong bunga ditemukan kadar hemoglobin abnormal sebanyak $15,7 \% .^{11}$ Anemia juga ditemukan pada pekerja penyemprot herbisida di perkebunan sawit Kabupaten Banyuasin sebanyak 30 dari 40 pekerja penyemprot. ${ }^{12}$

Pemeriksaan hemolobin secara berkala sangat penting dilakukan untuk skrining awal data gejala/tanda penyakit akibat kerja, akan tetapi hal ini belum dilakukan oleh puskesmas maupun klinik perusahaan. Oleh karena itu penelitian ini bertujuan untuk menganalisis kadar hemoglobin pekerja akibat paparan pestisida di perkebunan kelapa sawit. 


\section{METODE}

Penelitian ini merupakan penelitian observasional analitik dengan desain penelitian ini adalah potong lintang (cross sectional). ${ }^{13}$ Penelitian ini dilaksanakan di perkebunan kelapa sawit Kabupaten Banyuasin dari bulan Juli September 2016. Besar sampel hasil perhitungan menggunakan rumus dibawah ini: ${ }^{14}$

$$
\mathrm{n}=\frac{[\mathrm{Z} \alpha \times \mathrm{S}]^{2}}{\mathrm{~d}}
$$

\section{HASIL}

Hasil analisis univariat rerata kadar hemoglobin pekerja dan karakteristik pekerja,

paparan langsung dan perilaku pekerja dijelaskan pada tabel Tabel 1 dan Tabel 2 di bawah ini : perhitungan besar sampel diperoleh sebanyak 80 responden, sampel. Pemilihan sampel dilakukan secara acak sederhana.

Data dikumpulkan melalui wawancara langsung dengan pekerja menggunakan kuesioner, sedangkan kadar haemoglobin pekerja diperiksa menggunakan $\mathrm{Hb}$ meter digital easy touch.

Tabel 1. Rerata Kadar Hemoglobin pada Penyemprot Pestisida di Perkebunan Kelapa Sawit Kabupaten Banyuasin $(\mathbf{n}=\mathbf{8 0})$

\begin{tabular}{lllll}
\hline Variabel & Rerata & Median & $\begin{array}{c}\text { Standar } \\
\text { Deviasi }\end{array}$ & Kisaran \\
\hline Kadar Hemoglobin(gr/\%) & & & & \\
1. Pria & 13,69 & 13,55 & 1,979 & $10,7-19$ \\
2. Wanita & 12,6 & 12,6 & 1,435 & $10,2-16$ \\
\hline
\end{tabular}

Dari Tabel 1 dijelaskan bahwa rerata kadar hemoglobin pada pria yaitu 13,69 gr\% dengan kisaran antara 10,7 - 19 gr\%, sedangkan pada

Tabel 2. Distribusi Responden Berdasarkan Karakteristik Pekerja, Paparan Langsung dan Perilaku Pekerja Penyemprot Pestisida di Perkebunan Kelapa Sawit Kabupaten Banyuasin $(\mathbf{n}=\mathbf{8 0})$

\begin{tabular}{lcc}
\hline Variabel & Jumlah & $\begin{array}{c}\text { Persentase } \\
(\mathbf{\%})\end{array}$ \\
\hline Karakteristik Pekerja : & & \\
Umur & & \\
1. $\geq 37$ tahun & 44 & 55 \\
2. $<37$ tahun & 36 & 45 \\
Jenis Kelamin & & \\
1. Pria & 34 & 42,5 \\
2. Wanita & 46 & 57,5 \\
Masa Kerja & & \\
1. $\geq 3$ tahun & 35 & 43,8 \\
2. $<3$ tahun & 45 & 56,2 \\
Tingkat Pendidikan & & \\
1. Rendah & 70 & 87,5 \\
2. Tinggi & 10 & 12,5 \\
Kebiasaan Merokok & & \\
1. Ya & 22 & 27,5 \\
2. Tidak & 58 & 72,5 \\
\hline
\end{tabular}




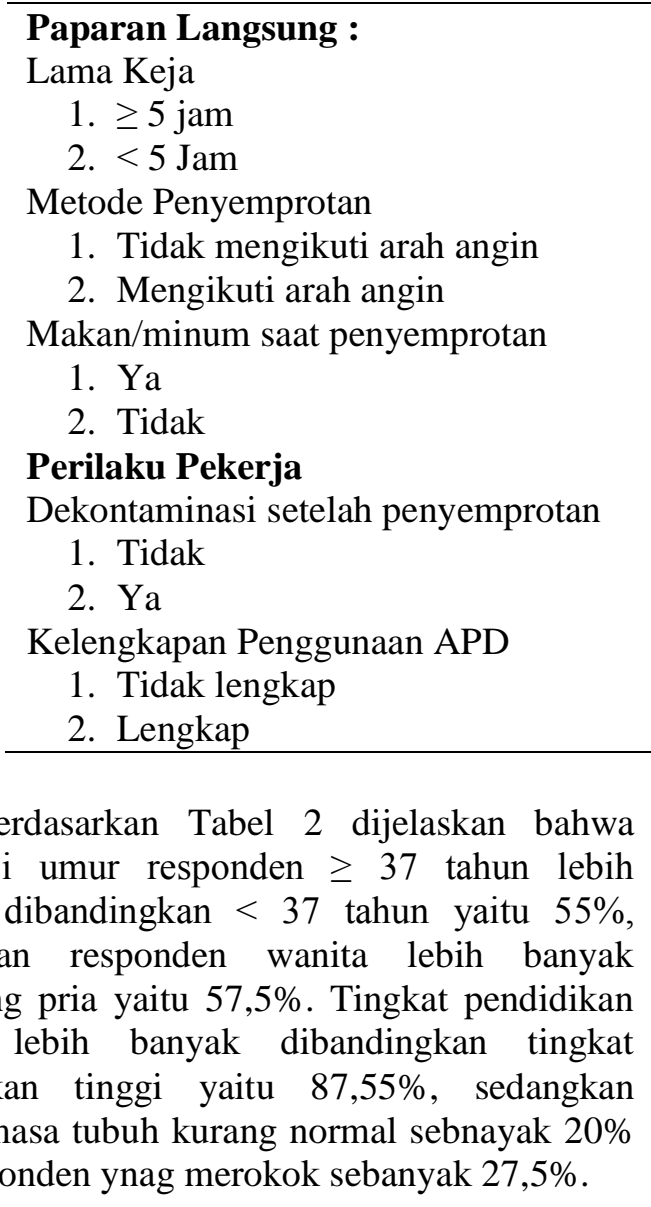

distribusi umur responden $\geq 37$ tahun lebih banyak dibandingkan $<37$ tahun yaitu 55\%, sedangkan responden wanita lebih banyak dibanding pria yaitu $57,5 \%$. Tingkat pendidikan rendah lebih banyak dibandingkan tingkat pendidikan tinggi yaitu $87,55 \%$, sedangkan indeks masa tubuh kurang normal sebnayak $20 \%$ dan responden ynag merokok sebanyak $27,5 \%$.

$\begin{array}{cc}76 & 95 \\ 4 & 5 \\ 37 & 46,2 \\ 43 & 53,8 \\ & \\ 62 & 77,5 \\ 18 & 22,5 \\ & \\ & \\ 43 & 53,8 \\ 37 & 46,2 \\ & \\ 39 & 48,8 \\ 41 & 51,2\end{array}$

Pekerja yang bekerja $\geq 5$ jam/hari sebanyak $95 \%$, responden yang bekerja $\geq 3$ tahun sebanyak $43,8 \%$, pekerja yang menyemprot tidak mengikuti arah angin sebanyak 46,2\% dan makan/minum saat aplikasi sebanyak $77,5 \%$. Dekontaminasi setelah penyemprotan pestisida sebanyak 53,8\% dan yang menggunakan alat pelindung diri tidak lengkap sebanyak $48,8 \%$.

Hasil analisis bivariat menggunakan uji $t$ dijelaskan pada tabel dibawah ini:

Tabel 3. Distribusi Rerata Kadar Haemoglobin berdasarkan Variabel Karakteristik Pekerja, Papapran Langsung dan Perilaku Pekerja di Perkebunan Kelapa Sawit Kabupaten Banyuasin $(\mathbf{n}=\mathbf{8 0})$

\begin{tabular}{llcc}
\hline Variabel & n & Mean & p value \\
\hline Umur & & & \\
1. $\geq 37$ tahun & 44 & 12,9 & 0,483 \\
2. $<37$ tahun & 36 & 13,2 & \\
Jenis Kelamin & & & \\
1. Pria & 34 & 13,7 & 0,005 \\
2. Wanita & 46 & 12,6 & \\
Tingkat Pendidikan & & & \\
1. Rendah & 70 & 12,8 & 0,001 \\
2. Tinggi & 10 & 14,7 & \\
Masa Kerja & & & \\
1. $\geq 3$ tahun & 54 & 13,0 & \\
2. $<3$ tahun & 26 & 13,2 & \\
Kebiasaan Merokok & & & \\
1. Ya & 32 & 13,6 & \\
2. tidak & 58 & 12,9 & 0,100 \\
Lama Keja & & & \\
1. $\geq 5$ jam & 77 & 13,05 & \\
2. <5 Jam & 3 & 13,2 & \\
\end{tabular}




\begin{tabular}{llll}
\hline $\begin{array}{l}\text { Metode Penyemprotan } \\
\text { 1. Tidak mengikuti arah }\end{array}$ & 37 & 13,3 & 0,215 \\
$\quad \begin{array}{l}\text { angin } \\
\text { 2. Mengikuti arah angin }\end{array}$ & 43 & 12,8 & \\
$\begin{array}{l}\text { Makan/minum saat } \\
\text { penyemprotan }\end{array}$ & 62 & 12,8 & 0,032 \\
$\quad$ 1. Ya & 18 & 13,8 & \\
2. Tidak & & 13,6 & 0,009 \\
$\begin{array}{l}\text { Kelengkapan Alat Pelindung Diri } \\
\text { 1. Tidak lengkap }\end{array}$ & 39 & 12,6 & \\
2. Lengkap & 41 & & \\
$\begin{array}{l}\text { Dekontaminisasi setelah } \\
\text { penyemprotan }\end{array}$ & & 13,8 & 0,001 \\
1. Tidak & 37 & 12,5 & \\
2. Ya & 43 & & \\
\end{tabular}

Berdasakan Tabel 3 variabel yang secara statistik berhubungan dengan kadar haemoglobin yaitu jenis kelamin, tingkat pendidikan, makan minum saat penyemprotan, penggunaan alat pelindung diri dan dekontaminasi setelah penyemprotan pestisida.

Tabel 4. Model Akhir Hasil Analisis Regresi Linier Ganda

\begin{tabular}{lccc}
\hline Variabel & B & $\begin{array}{c}\text { Beta } \\
\text { Standardized } \\
\text { Coefficients) }\end{array}$ & Nilai p \\
\hline Tingkat Pendidikan & 1,272 & 0,240 & 0,037 \\
Dekontaminasi penyemprotan & $-0,943$ & $-0,268$ & 0,020 \\
Konstan & 13,078 & & \\
$R$ Squared & 0,182 & & \\
\hline
\end{tabular}

Berdasarkan seleksi bivariat dari beberapa kandidat model yang dianalisis menggunakan regresi liner ganda yang masuk pada model akhir statistik yaitu tingkat pendidikan dan dekontaminasi setelah penyemprotan. Dari Tabel 4 dijelaskan bahwa variabel yang menjadi prediktor dalam menentukan kadar $\mathrm{Hb}$ pekerja

\section{PEMBAHASAN}

Berdasarkan hasil penelitian didapatkan anemia ditemukan lebih banyak dialami pekerja perempuan, hal ini disebabkan pekerja perempuan mengalami menstruasi setiap bulannya dan umur rata - rata masih produktif. Meskipun secara jumlah anemia hanya ditemukan 32 dari 80 pekerja penyemprot pestisida hal ini harus diantisipasi. Kondisi penurunan beberapa komponen hematologi seperti hemoglobin, hematokrit ditemukan terjadi pada petani anggur yang terpapar pestisida, ${ }^{15}$ sedangkan pada petani yang melakukan penyemprotan secara intensif di India juga terjadi yaitu tingkat pendidikan dan dekontaminasi setelah terpapar. Nilai $R$ Square sebesar 0,182 ini berarti kedua variabel tersebut hanya dapat menjelaskan pengaruhnya terhadap kadar $\mathrm{Hb}$ pekerja sebesar $18,2 \%$ selebihnya dijelaskan variabel lain.

penurunan kadar hemoglobin. ${ }^{16}$ Pada aplikator herbisida di perkebunan kelapa sawit PT. SAL Kabupaten Banyuasin didapatkan bahwa responden yang anemia sebanyak 30 dari 40 responden $(75 \%) .{ }^{12}$ Selain itu kadar $\mathrm{Hb}$ penyemprot gulma di PT. Agro Indomas dengan kategori anemia sedang (kadar $\mathrm{Hb}$ responden 8 $\mathrm{g} / \%$ - $10 \mathrm{gr} / \%$ ) sebanyak $93,8 \%$ dan anemia berat (6 gr/\% - 7,9gr/\%) sebanyak 6,2\%. ${ }^{7}$ Pada petani penyemprot pestisida di Brebes dilaporkan bahwa yang mengalami anemia sebanyak 5 respnden $(15,6 \%),{ }^{9}$ sedangkan pada petani hortikultura di 
Desa Tejosari Magelang yang mengalami anemia sebanyak 63 orang $(80,8 \%){ }^{8}$

Umur merupakan salah satu faktor yang mempengaruhi kadar hemoglobin pada pekerja penyemprot pestisida diperkebunan sawit. Hasil Penelitian menunjukkan bahwa responden yang berumur $\geq 37$ tahun lebih banyak, dimana rerata kadar $\mathrm{Hb}$ pada kedua kelompok umur tersebut masih normal. Hal ini sesuai penelitian yang dilaporkan pada kelompok umur $\geq 40$ tahun rerata kadar $\mathrm{Hb}$ juga normal. ${ }^{17}$ Kelompok umur ini juga merupaka kelompok usia produktif. Selain itu paparan pestisida pada pada pemotong bunga kelompok umur yang paling banyak adalah 20 - 35 tahun. ${ }^{11}$ Umur merupakan salah satu faktor demografi yang mempengaruhi persepsi dan kondisi kesehatan tubuh seseotang. Tidak ada batasan minimal seseorang untuk menjadi seorang pekerja, namun pada pekerja penyemprot pestisida di perkebunan sawit.

Hasil penelitian menunjukkan bahwa responden wanita lebih banyak yang mengalami penurunan hemoglobin dan dikategorikan anemia. Kondisi ini disebabkan karena pekerja perempuan yang melakukan penyemprotan pestisida adalah kelompok pekerja dengan usia produktif dan belum menopause. Sesuai penelitian di desa Rurukan rerata kadar hemoglobin pada petani perempuan sebesar 13,28 $\mathrm{g} / \mathrm{dL}$ dan rerata kadar hemoglobin pada responden laki-laki sebesar 14,49 $\mathrm{g} / \mathrm{dL}$ ini menujukkan kadar hemoglobin wanita ditemukan lebih rendah dibandingkan pria. ${ }^{17}$

Hasil penenlitian menunjukkan bahwa responden yang berpendidikan rendah lebih banyak dibandingkan yang berpendidikan tinggi. Hal ini sesuai dengan penelitian yang dilakukan pada petani hortikultura di desa Gembomg rsponden yang berpendidikan dasar sebanyak 37 $(92,5 \%),{ }^{6}$ sedangkan pada penyemprotan gulma di perkebunan kelapa sawit PT.Agro Indomas Seruyan Kalimantan Tengah semua responden berpendidikan rendah. ${ }^{7}$ Tingkat pendidikan merupakan pendidikan formal yang ditempuh pekerja sehingga semakin tinggi pendidikan pekerja maka semakin muda pekerja untuk menerima informasi terkait dengan penggunaan herbisida.

Hasil penelitian menunjukkan bahwa responden yang bekerja $\geq 3$ tahun lebih banyak dibandingkan yang $<3$ tahun. Hal ini sesuai dengan penenelitian pada petani holtikultura di desa Gombong responden yang bekerja $>5$ tahn sebanyak $36(90 \%)$ dan yang $\leq 5$ tahun sebanyak $4(10 \%){ }^{6}$ Namun pada pekerja penyemprot gulma masa kerja ditemukan lebih banyak $\geq 1$ tahun yaitu $88,3 \%$. $^{7}$ Semaki lama seseoarang bekerja sebagai penyemprot maka akan semakin sering terpapar dan kontak dengan bahan aktif pestisida.

Responden yang tidak merokok lebih banyak dibandingkan dengan yang merokok. Hal ini karena responden yang bekerja sebagai penyemprot pestisida lebih banyak wanita dibandingkan pria. Sesuai penelitian sebelumnya bahwa pekerja yang merokok sebanyak 28,8\% dan $53 \% .^{18,19}$ Namun perlu diwaspadai kebiasaan merokok saat melakukan aplikasi pestisida secara tidak sengaja dapat menyebabkan masuknya pestisida melalui hisapan rokok.

Hasil penelitian menunjukkan bahwa responden yang menyemprot $\geq 5 \mathrm{jam} /$ hari lebih banyak, ini menunjukkan bahwa lama penyemprotan ini melebihi batas waktu yang telah ditentukan peraturan kementerian pertanin. Hal ini sesuai penelitian di perkebunan sawit di Kabupaten Banyuasi dimana banyak pekerja yang menyemprot $\geq 7$ jam $/$ hari yaitu $65 \%$. Hal ini tidak sesuai dengan peraturan menteri pertanian seorang pekerja hanya boleh terpapar pestisida 4-5 jam. ${ }^{20}$ Sedangkan pada penyemprot gulma yang menyemprot $<5$ jam/hari sebanyak $100 \%{ }^{7}$ Lama kerja merupakan waktu yang diperlukan pekerja untuk melakukan aktivitas pekerjaan dalam sehari, semakin lama pekerja bekerja, maka semakin sering pekerja kontak dengan bahan aktif pestisida sehingga mengakibatkan. bahan aktif pestisida dapat masuk dan terakumulasi dalam tubuh pekerja.

Hasil penelitian menunjukkan bahwa pekerka lenbih banyak yang memperhatikan arah angin saat melakukan aplikasi penyemprotan di lapangan. Metode penyemprotan dengan memperhatikan arah angin akan membantu mengurangi masuknya herbisida yang disemprotkan dalam bentuk embun terutama melalui rute pernapasan. Dalam pedoman pembinaan penggunaan pestisida juga telah ditentukan bahwa saat aplikasi, tidak boleh sambil makan/minum/merokok di area perkebunan dan tidak menyentuh mulut/hidung/muka dengan tangan yang terkontaminasi pestisida. ${ }^{20}$

Hasil penelitian menunjukkan bahwa pekerja yang menyentuh mulut/hidung saat melakukan penyemprotan lebih banyak dibandingkan dengan yang makan/minum. Hal ini karena saat aplikasi bekerja sering menghapus keringat pada bagian muka menggunakan tangan yang telah terkontaminasi dengan bahan aktif 
herbisida. Selain itu pada pedoman pembinaan penggunaan pestisida juga telah ditentukan bahwa saat aplikasi, tidak boleh sambil makna/minum/merokok di area perkebunan dan tidak menyentuh mulut/hidung/muka dengan tangan yang terkontaminasi pestisida. ${ }^{20}$

Hasil penelitian menunjukkan bahwa responden yang menggunakan alat pelindung diri secara lengkap dibandingkan yang tidak lengkap , tetapi alat pelindung diri yang digunakan belum sesuai dengan standar yang telah ditetapkan. Penggunaan APD saat penyemprotan sangat berpengaruh terhadap jumlah masuknya partikel herbisida kedalam tubuh penyemprot. Sesuai penelitian pada pekerja penyemprot gulma yang menggunakan alat pelindung diri yang tidak lengkap sebanyak $100 \% .^{7}$ pada petani holtikultura juga dilaporkan bahwa petani yang menggunakan APD secara tidak lengkap pada saat penyemprotan yaitu sebanyak 74 responden $(94,9 \%) .{ }^{8}$ Hal ini disebabkan oleh saat aplikasi cuaca panas sehingga pekerja merasa tidak nyaman saat menggunakan pelindung diri secara lengkap.

Hasil penelitian menunjukkan bahwa pekerja lebih banyak yang tidak melakukan

\section{KESIMPULAN DAN SARAN}

Kadar hemoglobin pekerja perkebunan kelapa sawit akibat paparan pestisida di pengaruhi oleh beberapa variabel diantaranya tingkat pendidikan, makan/minum saat melakukan penyemprotan atau di lokasi penyemprotan. Meskipun kadar hemoglobin kurang dari normal ditemukan hanya 26 pekerja

\section{UCAPAN TERIMA KASIH}

Penulis mengucapan terima kasih kepada pihak manajemen kelapa sawit yang telah memfasilitasi penelitian ini sampai dengan selesai dan kepada

\section{DAFTAR PUSTAKA}

1. Peraturan Menteri Pertanian (Permentan) Nomor: 42 /Permentan/SR/140/5/2007 tentang Pengawasan Pestisida.

2. Dinas Perkebunan Provinsi Sumatera Selatan, 2013. Statistik Perkebunan.

3. Terry, AV. 2012. Functional consequences of repeated organophosphate exposure: Potential non-cholinergic mechanisms. Pharmacol. Ther. 134, 355-365. dekontaminasi setelah penyemprotan. Hal ini karena ruang untuk dekontaminasi tidak tersedia di area perkebunan. Sesuai penelitian yang dilaporkan bahwa insiden keracunan disebabkan pekerja makan tanpa mencuci tangan setelah paparan dengan herbisida paraquat. ${ }^{21}$ Selain itu juga di Nepal dilaporkan bahwa total 52\% wanita dan $42 \%$ pria tidak mencuci tangan/membersihkan tubuh setelah menyemprot. ${ }^{22} \mathrm{Hal}$ ini karena tidak tersedianya tempat untuk melakukan dekontaminasi di area perkebunan. Namun hal berbeda dilaporkan bahwa lebih dari 8.500 pekerja mengatakan bahwa mereka mencuci tangan segera setelah penyemprotan sebanyak $77 \%$. ${ }^{23}$ Dekontaminasi merupakan hal penting dilakukan pekerja terutama setelah melakukan penyemprotan pertisida untuk meminimalisir masuknya bahan aktif paraquat ke dalam tubuh pekerja. Hal lain yang tidak diketahui pekerja yaitu dekontaminasi pakaian setelah melakukan aplikasi penyemprotan harus diganti dan dicuci terpisah dengan pakaian yang tidak terkontaminasi paraquat. Ini dikarenakan ketidaktahuan pekerja dan kurangnyainformasi mengenai hal-hal terkait dengan personal hygin setelah terpapar pestisida.

dari 80 pekerja hal ini perlu diwaspadai dan harus dilakukan pemeriksaan secara berkala.

Oleh karena itu pemeriksaan kadar hemoglobin perlu dilakukan secara berkala oleh pihak puskesmas maupun klinik perusahaan, selain itu juga program gizi pekerja sangat penting dilakukan di perusahaan.

mahasiswa yang telah membantu dalam penelitian ini.

4. Maksuk, Tan Malaka, Suheryanto, Umayah A, 2016. Risk Factors Related to Dermal Exposure on Herbicide Applicators (Case Study in Palm Oil Banyuasin District, South Sumatera), Proceeding of The $6^{\text {th }}$ Annual Basic Scince International Conference, Brawijaya University, ,http://basic.ub.ac.id/files/proceeding/PROC EEDINGS-BASIC-2016.pdf 
5. Murray RK, Granner Daril K, Rodwell Victor W, 2009. Biokimia Herper (harper's illustrated biochemistry) / Alih bahasa: Brahm U.Pendit; Editor: Nanda Wulandari.et al., Jakarta, EGC.

6. Kurniasih, S.A, Onny, S, Achadi, N,S. 2013. Faktor-faktor yang Terkait Paparan Pestisid dan Hubungannnya dengan Kejadian Anemia pada Petani Hortikultura di Desa gombong Kecamatan Belik Kabupaten Pemalang Jawa Tengah, Jurnal Kesehatan Lingkungan Indonesia, 12 (2):132-137.

7. Djau, R.A, 2009. Faktor Resiko Kejadian Anemia dan Keracunan Pestisida Pada Pekerja Penyemprot Gulma di Kebun Kelapa Sawit PT. Agro Indomas Kabupaten Seruyan Kalimantan Tengah, Tesis Proram Pasca Sarjana Universitas Diponegoro Semarang.

8. Rastogi,SK,Sigh VK,Kasavachandran C,Jyoti, Siddiqui M.K.J, Mathur,N Bharti RS,2008. Monitoring of Plasma Butyrylcholinesterase Activy and Hematologocal Parameters in Pesticide Sprayers, Indian Journal of Occupational \& Enviromental Medicine, 12 (1): 29-32. DOI:10.4103/0019-5278.40813.

9. Fikri E, Setiani O, Nurjazuli, 2012. Hubungan Paparan Pestisida dengan Arsen dalam Urin dan Kejadian Anemia, Jurnal Kesehatan Lingkungan Indonesia ,11 (1):2937.

10. Runia, YA, 2008, Faktor-faktor Yang berhubungan Dengan Keracunan Pestisida Organosfosfat, Karbamat dan kejadian Anemia pada Petani Hortikultura Di Desa Tejosari Kecamatam Ngablak Kabupaten magelang, Tesis Program studi Megister Kesehatan Lingkungan Universitas Diponegoro.

11. Del Prado Lu, 2007. Pesticide exposure, risk factors and health problem among cut flowers : across sectional study, Journal of Occupational Medicine and Toxicolocy, 2(9):1-8.

12. Maksuk, Andani P, Suzanna, Amin M. 2017. Analisis Faktor Risiko Kejadian Anemia Pada Aplikator Herbisida (Studi Kasus Di Perkebunan Kelapa Sawit PT. S Kabupaten Banyuasin), Jurnal Ilmu Kesehatan Masyarakat, Maret 2017, 8(1):34-42. http://www.jikm.unsri.ac.id/ index.php/jikm/issue/view/40
13. Notoatmodjo S, 2010. Metodologi Penelitian Kesehatan, Edisi Revisi, Rineka Cipta, Jakarta.

14. Dahlan S, 2010. Besar Sampel dan Cara Pengambilan Sampel, Salemba Medika, Jakarta.

15. Patil JA, Patil AJ, Govindwar SP. Biochemical effects of varous pesticides on sprayers of grape gardens. Indian journal of clinical biochemistry, 2003;18(2):16-22 6.

16. Reddy PB, Jagdish K. Clinico Pathological effects of pesticides exposure on farma workers. 2012. DAV International Journal of Science.;1(2):119-121.

17. Rangan, A, supit, S,Nancy, E J, 2013. Kadar Hemoglobin Pada Petani Terpapar Pestisida di Kelurahan Rurukan Kecamatan Tomohon Timur. Skripsi Fakultas Kedokteran Universitas Sam Ratulangi.

18. Jayasumana C, Paranagama P, Agampodi S, Wijewardane C, Gunatilake S, Siribaddana S, 2015. Drinking well water and occupational exposures to herbicides is associated with chronic kidney disease, in Padavi-Sripura, Sri Lanka, BioMedCentral, 14(6): 2-10.

http://www.ehjournal.net/content/14/1/6 .

19. Waggoner JK, Henneberger PK, Kullman GJ, Umbach DM, Kamel F, Beane LE, Freeman, Alavanja Michael C. R, Sandler DP., Hoppin JA, 2013. Pesticide use and fatal injury among farmers in the Agricultural Health Study, Int Arch Occup Environ Health, 86:177-187. DOI 10.1007/s00420-012-0752-x.

20. Kementerian Pertanian Direktorat Sarana dan Prasarana Pertanian 2011. Pedoman Penggunaan Pestisida Pertanian.

21. Corriols $m \&$ Aragon, 2010. Chil Labor and Acute Pesticide Poisining in Nacaragua. Failure to Comply with Chlidren's Rights. International Journal of Occuptional and Environmental Health, 16:193-200.

22. Kishor Atreya, 2007. Pesticide use knowledge and practices: A gender difference in Nepal. Environmental Research, 104 (2): 305-311.

23. Mattews GA, 2008. Attitudes and behaviours regarding use of crop protection products-A survey of more than 8500 smallholders in 26 countries. Crop Protection, 27:843-846. 